\title{
BIZTONSÁGPOLITIKA
}

\author{
Zsolt Melinda
}

\section{A jövô homályába vész az energiaszuverenitás megoldása Az energiabiztonság szerepe Magyarország Nemzeti Biztonsági Stratégiájában}

https://doi.org/10.17047/HADTUD.2020.30.3.3

2020. április 21-én megjelent Magyarország új Nemzeti Biztonsági Stratégiája, melyben elôdeihez képest lényegesen hangsúlyosabb szerepet kap az energia, az energiabiztonság és ezekhez kapcsolódva a klímaváltozás kérdésköre. A dokumentum 21. századi, modern szemléletet tükröz ebben a témában, de számos ellentmondás is felfedezhetô. Kérdéseket vet fel például, hogy a paksi beruházás mennyiben lesz képes beváltani a hozzá fúzött elvárásokat a dekarbonizációs célok teljesítésében. A modern megközelítésbe szintén nem illeszkedik az, hogy szénalapú technológiára épül Magyarország stratégiai tartaléka. A dokumentum összhangban van az EU és a NATO biztonságfelfogásával. A biztonsági kockázatok prioritásai azonban nem tükrözik a magyar társadalom biztonságpercepcióját.

KULCSSZAVAK: energiabiztonság, klímaváltozás, importfüggőség, megújuló energiák, nukleáris energia

\section{The solution to energy-souvereinty obscured by the future}

The role of energy security in Hungary's National Security Strategy

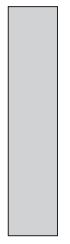

On 21 April 2020, Hungary's new National Security Strategy was released, in which the issues of energy, energy security, and related climate change are given a much more prominent role than in its predecessors. The document represents a modern, 21st-century approach to this topic, but a number of contradictions can also be discovered. For example, it raises questions about the extent to which the Paks investment will be able to live up to expectations in meeting decarbonisation targets. The fact that Hungary's strategic reserve is based on coal-based technology is not in line with the modern approach either. The document - with a few

\footnotetext{
४) Nemzeti Közszolgálati Egyetem, Hadtudományi és Honvédtisztképző Kar, Hadtudományi Doktori Iskola National University of Public Service, Faculty of Military Science and Officer Training, Doctoral School of Military Sciences; e-mail: zsolt.melinda@uni-nke.hu; ORCID: 0000-0002-3826-8323
} 
exceptions - basically meets the requirements of a modern interpretation of energy security, is in line with the security perceptions of the two most important international organizations for Hungary's security, the EU and NATO, and the Hungarian sectoral strategy documents. The priorities of security risks do not reflect the security perception of Hungarian society.

KEYWORDS: energy security, climate change, import dependence, renewable energies, nuclear energy

\section{Bevezetés}

A magyar kormány 2020. április 21-én mutatta be Magyarország új Nemzeti Biztonsági Stratégiáját, azaz nyolc év telt el ugyanennek a dokumentumnak az előző verziója megalkotása óta. A dolgozat célja, hogy bemutassa, hogy a most született Nemzeti Biztonsági Stratégia hogyan viszonyul az energia és az energiához kapcsolódva a klímaváltozás kérdéseihez, mekkora jelentőséget tulajdonít ezeknek a globális biztonsági környezetben, és milyen szerepet szán Magyarországnak az ezekhez a területekhez kapcsolódó hazai és nemzetközi folyamatokban. A dolgozat kitér arra is, hogy a magyar stratégiai dokumentumokban hogyan jelennek meg a Nemzeti Biztonsági Stratégia iránymutatásai, valamint hogy a magyar dokumentumokban foglaltak hogyan viszonyulnak a biztonság szempontjából releváns nemzetközi szervezetek, az EU és a NATO biztonságpercepciójához, iránymutatásaihoz.

\section{A biztonság átfogó értelmezése}

A Nemzeti Biztonsági Stratégia ${ }^{1}$ bevezetôje a globális biztonsági környezet változásaival indokolja a dokumentum megalkotását, amelynek tényezói között rögtön említi a klímaváltozás felgyorsulását és a természeti erôforrások kimerülését. A dokumentum a nemzeti jövóképról szóló fejezetben felvázoltak alapján Magyarország biztonságának zálogát a fenntartható fejlődés feltételeinek biztosításában látja, amelynek gazdasági alapját a nemzetközi versenyképesség fokozása képezi.

Az alapvetó értékeinkról szóló fejezetból kiderül, hogy a dokumentum a biztonságot átfogóan értelmezi, és a hagyományos katonai biztonságot kiszélesítve beszél politikai, gazdasági, pénzügyi, társadalmi, technológiai, környezeti, egészségügyi, katonai, rendészeti, információs és kibertérbeli biztonságról is.

A biztonság átfogó értelmezése megjelenik az első, 2002-ben megjelent Nemzeti Biztonsági Stratégiában, ${ }^{2}$ az a dokumentum ugyanakkor nem foglalkozik érdemben az energiabiztonság területével.

A 2004-es stratégiában ${ }^{3}$ is az átfogó értelmezés a meghatározó, és az akkori biztonsági környezetnek megfelelően "a hagyományos politikai és védelmi tényezók mellett, többek között, gazdasági, társadalmi, ezen belül emberi és kisebbségi jogi, valamint környezeti elemeket" tartalmaz. Jelen elemzés szempontjából fontos, hogy megjelenik a dokumentumban az energiabiztonság fogalma, mint a gazdaságbiztonság kiemelten

1 A Kormány 1163/2020. (IV. 21.) Korm. határozata Magyarország Nemzeti Biztonsági Stratégiájáról.

2 A Kormány 2144/2002. (V. 6.) Korm. határozat a Magyar Köztársaság Nemzeti Biztonsági Stratégiájáról.

3 A Kormány 2073/2004. (IV. 15.) Korm. határozat a Magyar Köztársaság Nemzeti Biztonsági Stratégiájáról. 
fontos területe, részletekbe azonban nem bocsátkozik. A klímaváltozás ugyanakkor nem szerepel, a természet pusztítása, a környezet szennyezése és a szúkös erő́forrásokért folytatott küzdelem ezzel szemben hangsúlyos elemként jelenik meg.

A 2012-ben született Nemzeti Biztonsági Stratégia ${ }^{4}$ ugyancsak átfogóan értelmezi a biztonságot, de a mostaninál egy szúkebb területet nevesít. „Mára elengedhetetlenné vált a biztonság politikai, katonai, gazdasági és pénzügyi, társadalmi, ezen belül emberi és kisebbségi jogi, valamint környezeti dimenziójának együttes kezelése."

Jól látszik tehát, hogy az energiabiztonságot a gazdaságbiztonság alrendszereként kell értelmezni, de sajátosságaiból adódóan egyes vetületei érintik a biztonság többi szektorát.

\section{Energiafüggóség: az EU és Magyarország}

A dokumentum az alapvetố adottságaink áttekintésekor leszögezi, hogy Magyarország a globális, de különösen az európai értékteremtési láncba mélyen integrálódott, ami alapvetốn számos elônnyel jár, de sebezhetőséget is hordoz magában. Megállapítja, hogy "természeti eröforrásaink korlátozottak, külső tókebefektetési szükségletünk és importfüggóségünk magas, a magyar gazdaságban az export meghatározó".

Magyarország energiaellátásának túlnyomó része importból származik, különösen nagy a kitettsége a fosszilis energiahordozóknak, így amikor energiabiztonságról beszélünk, akkor az energiafüggóségból adódóan az ellátás biztonsága kerül fókuszba. Az energiabiztonság ebben az értelmezésben azt jelenti, hogy folyamatosan és zavartalanul hozzá lehet férni a megfelelố mennyiségú energiához megfizethetó áron. A Nemzetközi Energiaügynökség definíciója szerint ${ }^{5}$ a fejlett világban az energiabiztonság definíciója pont így hangzik. Kiegészül azzal, hogy ha egy ország rövid és hosszú távú céljait és érdekeit vizsgáljuk, az energiabiztonság értelmezése eltér. Rövid távon az akut energiabiztonsági problémák kezelését kell szem előtt tartani, azaz hogy az energetikai rendszerek képesek legyenek gyorsan reagálni a kereslet-kínálat egyensúlyának hirtelen változásaira. Hosszú távon viszont a legfontosabb szempont, hogy az energetikai beruházások a gazdasági fejlódést és ezzel együtt a környezeti fenntarthatóságot szolgálják.

\section{Az EU és a NATO: klíma és energia}

Magyarország biztonsági környezetének vizsgálatakor a stratégia azonnal leszögezi, hogy a jelenlegi szilárd biztonsági helyzetet az EU és a NATO tagságunk tovább növeli.

Az EU kiemelt ügyként kezeli az energia és a klíma területeit, ennek keretet adva döntött az energiaunió létrehozásáról. Az Európai Bizottság 2015-ben mutatta be az energiaunió stratégiáját, ${ }^{6}$ ami öt pillérre épül:

4 A Kormány 1035/2012. (II. 21.) Korm. határozata Magyarország Nemzeti Biztonsági Stratégiájáról.

5 International Energy Agency: Energy security. https://www.iea.org/topics/energysecurity/ (Letöltés ideje: 2020. 05. 30.)

6 European Commission: Energy Union.

https://ec.europa.eu/energy/topics/energy-strategy/energy-union_en (Letöltés ideje: 2020. 05. 30.) 
1) energiabiztonság: az energiaforrások diverzifikációja, szolidaritás és együttmúködés a tagállamok között;

2) teljesen integrált belső energiapiac: az energia akadálytalan továbbjutása a megfeleló infrastruktúrán keresztül;

3) energiahatékonyság: az importfüggőség csökkenése, kibocsátás-csökkenés, munkahelyteremtés, gazdasági növekedés;

4) fellépés a klímaváltozás ellen, a gazdaság dekarbonizációja: a Párizsi Klímaegyezmény megvalósítása, vezető szerep a megújuló energiák terén;

5) kutatás, innováció, versenyképesség: alacsony kibocsátású és tiszta energiára épülő technológiák, az energiaátmenet elômozdítása.

Az energiaunió összességében azokra a kihívásokra ad választ, amelyekkel az EU energia, illetve ezzel összefüggésben a klíma témájában szembesül. A 2030-ig kitúzött célok közül az egyik legfontosabb az energiahatékonyság növelése 32,5 százalékkal, a másik a megújuló energiaforrások részarányának növelése 32 százalékkal, a harmadik pedig az üvegházhatású gázok kibocsátásának csökkentése 40 százalékkal.

Az energiaunió tehát elkötelezett a klímaváltozás elleni küzdelem mellett, azzal a céllal, hogy az EU 2050-re klímasemlegessé váljon. A világ legnagyobb energiaimportőreként további célja az energiafüggőség csökkentése, illetve a teljesen integrált belső energiapiac megteremtése egy korszerúbb energetikai infrastruktúra fejlesztésével. Ugyancsak az energiaunió elóírása, hogy a tagállamok nemzeti energia- és klímaterveket készítenek, amelyben beszámolnak a nemzeti hozzájárulásról az energiaunió céljainak eléréséhez. Magyarország elsó ilyen, 10 évre szóló nemzeti energia- és klímaterve 2020 januárjában készült el, ennek tartalmi elemeire késóbb visszatérünk.

Az EU esetében fontos még áttekinteni az energiabiztonság kérdését a kül- és biztonságpolitikára vonatkozó globális stratégiában.7 A 2016-ban bemutatott dokumentum természetesen utal az energiaunió célkitúzéseire, és törekvéseit úgy fogalmazza meg, hogy azok támogassák ezeknek a céloknak az elérését. Elsósorban az energetikai diplomácia eszközét alkalmazva képzeli el a szükséges források biztosítását. Külön hangsúlyozza az Európán kívüli szereplók bevonásakor az átláthatóság fontosságát, éppen a belső energiapiac múködésének biztonsága érdekében. Az integrált energiapiac esetében a fenntarthatóságra és az energiahatékonyságra összpontosít, valamint az infrastruktúra fejlesztésekor figyel a kétirányú szállítás és a cseppfolyósított földgáz (LNG) becsatornázásának lehetőségére. Az energiabiztonsághoz kapcsolódóan is említi a kiberbiztonság fontosságát, valamint többször elókerül az energiaátmenet a klímaváltozáshoz kötődően.

A NATO biztonságpercepciójában ugyancsak egyre fontosabb szerepet tölt be az energia és a klíma. Ugyan az energia nem tartozik elsódlegesen a politikai-katonai szövetség profiljába, de közvetlenül befolyásolja a nemzetközi biztonsági környezetet, és számos tagállam esetében hosszú távú biztonsági következményekkel járhat. ${ }^{8}$

7 Közös jövókép, közös fellépés: Erôsebb Európa - Globális stratégia az Európai Unió kül- és biztonságpolitikájára vonatkozóan. http://www.eeas.europa.eu/archives/docs/top_stories/pdf/eugs_hu_.pdf (Letöltés ideje: 2020. 05. 31.)

8 NATO's role in energy security. 14 September 2018.

https://www.nato.int/cps/en/natohq/topics_49208.htm (Letöltés ideje: 2020. 05. 31.) 
A NATO érdeke tehát az, hogy a szövetség és a tagállamok rendelkezzenek stabil és megbízható energiaellátással, hogy diverzifikálják a beszállítók körét, az ellátási útvonalakat és az energiaforrásokat, illetve, hogy megvalósuljon az energiahálózatok összekapcsolhatósága. A NATO tehát szorosan követi az energiapiaci trendeket, változásokat, párbeszédet folytat a szövetségen belül és a partnerekkel, szakértókkel, nemzetközi szervezetekkel, így kiemelten kezeli az Európai Uniót, a Nemzetközi Energiaügynökséget (IEA) és a Nemzetközi Megújulóenergia-ügynökséget (IRENA).

$\mathrm{Az}$ energiabiztonság politikai és gazdasági hátterének megteremtésén túl a NATO figyelmet fordít a kritikus energetikai infrastruktúrák védelmére. Ez a feladat alapvetóen nemzeti hatáskörbe tartozik, ugyanakkor ezek a rendszerek jellemzôen átívelnek határokon, és olyan fenyegetésektól kell megvédeni óket, amelyek szövetségi szintú fellépést igényelnek. Ilyenek például a terror-, a kiber- és a hibrid támadások. A NATO tehát fejleszti azon képességeit, amelyekkel hozzájárulhat a nemzeti erófeszítésekhez az energiabiztonság terén.

A harmadik kiemelt terület a NATO energiabiztonsági tevékenységében a hadseregek energiahatékonyságának javítása, ami egyrészt csökkenti a környezeti terhelést, emellett javítja a múveletek biztonságát, a mobilitást, illetve hosszabb idejú, nagyobb földrajzi távolságot lefedő múveleteket tesznek lehetôvé.

\section{Klímaváltozás, migráció, túlnépesedés, szúkülő eróforrások}

A dokumentum a biztonsági kihívásokat változó jellegúnek ítéli, és arra számít, hogy egyes tendenciák a biztonsági környezet romlását vetítik előre. Ezek közül jelen elemzés szempontjából a klímaváltozás, a migráció kiváltó okai és következményei, a túlnépesedés, illetve az eróforrások szúkössége a kiemelten fontosak, és összességében ez a négy tényező szorosan össze is függ egymással. A dokumentum ki is fejti, hogy "a világban zajló nagyléptékú gazdasági, társadalmi, demográfiai és környezeti változások és az egyre szúkösebb globális eróforrásokért folyó verseny jelentốs feszültségek forrása. A változások elsődleges jellemzóje, hogy azok sokszor összeolvadnak, felgyorsulnak és komplex kihívásokat generálnak".

Foglalkozik a klímaváltozás és a szélsőséges időjárás hatásaival az államok belső múködésére. Leszögezi, hogy a klímaváltozás hatásai mindenhol érzékelhetôek, az amúgy is jelenlévő nehézségek és sérülékenységek felerősödhetnek, így a már meglévố gazdasági és társadalmi problémák még súlyosabbá válhatnak.

A dokumentum - a migráció kiváltó okainak vizsgálatát követóen, de nem annak magyarázatául - rámutat, hogy Afrika és Ázsia számos térségében súlyos kihívást jelent az ivóvíz és az élelmiszer biztosítása a lakosság számára. A dokumentum ugyanebben a pontjában szerepel az is, hogy „a megújuló energiák és a környezetbarát technológiák növekvő hányadot képviselnek a globális energiaellátásban". A két gondolat közti összefüggés magyarázatára ugyan nem tér ki, de itt több kapcsolódási pont is lehetséges. Az egyik például, hogy a klímaváltozás káros hatásai leginkább a harmadik világot érintik, így a szén-dioxid-kibocsátás csökkentését támogató technológiák hozzájárulnak ahhoz, hogy az említett régiókban a lakosság életminőségének romlása ne legyen olyan drasztikus. Emellett a megújuló energiák alkalmazása decentralizált módon, akár háztartási méretben is történhet, ami könnyebben elérhetô a kevésbé fejlett 
energetikai infrastruktúrával rendelkezó térségekben is. Az energiaellátás javítása pedig ugyancsak segíti a jobb életminôséget.

A biztonsági környezet szempontjából önmagában is fontos értelmezni az állítást, hogy „a megújuló energiák és a környezetbarát technológiák növekvó hányadot képviselnek a globális energiaellátásban". Az energiaszektor globális átalakulása zajlik, ami jelentôs geopolitikai változásokat is magával hoz, márpedig az átalakuló globális és regionális eróviszonyok hatást gyakorolnak Magyarország biztonságára.

Azok az eróközpontok, ahol földrajzilag koncentrálódtak a fosszilis energiahordozók lelóhelyei, fokozatosan veszítik el jelentôségüket, miközben a megújuló energiaforrásokra épülő technológiák egyre versenyképesebbé válnak, és egyre nagyobb szeletet hasítanak ki a globális energiamixból. ${ }^{9}$ Mindez együtt jár azzal, hogy bizonyos mértékben minden állam függetlenebbé válik, hiszen képes megújuló forrásból biztosítani energiaigényének legalább egy részét. A megújulók térhódítását tovább erôsíti, hogy alkalmazásukkal érdemben lehet felvenni a versenyt olyan globális kihívások ellen, mint a klímaváltozás vagy az egyre nagyobb közegészségügyi problémává váló légszennyezés.

Ehhez a gondolatmenethez szorosan kapcsolódik a dokumentum azon megállapítása, hogy a lakosság létfenntartásához szükséges javak szúkössége jelentôs államközi és államokon belüli konfliktusokhoz vezethet. A természeti eróforrások iránti igény növekszik, ami súlyos környezeti károkat okoz, és azzal fenyeget, hogy ezek az eróforrások kimerülnek, így megszerzésük egyre nagyobb erófeszítést igényel, ami tovább fokozhatja a feszültséget. A társadalmi stabilitás fenntartása ebból következóen ugyancsak kihívásként jelenik meg, ami közvetlen hatást gyakorol a gazdasági és a pénzügyi stabilitásra. A dokumentum szerint a változó biztonsági környezet kockázatot jelent a források és szállítókapacitások szempontjából, azaz diverzifikálni kell Magyarország energiaimportját.

\section{Az energiabiztonság koncepciója}

A diverzifikáció az energiafüggőség csökkentésének egyik legkézenfekvóbb módja, diverzifikálni pedig lehet a külsó beszállítók körét, az energiaforrásokat, valamint az ellátási útvonalakat. Ezek az eszközök azonban önmagukban nem garantálják a kiegyensúlyozott ellátást, a megfelelő rugalmasság és ellenállóképesség kialakításához további lépések is szükségesek. Az energiabiztonság koncepciójának áttekintéséhez a Daniel Yergin által összefoglalt tételeket vesszük alapul. ${ }^{10}$ Yergin szerint a diverzifikációt követóen a második összetevő egy tágan értelmezett biztonsági tartalék kialakítása az energiaellátó rendszerben, ami képes az esetleges ellátási ingadozásból vagy bármilyen előre nem látható eseményból adódó különbözetet kiegyenlíteni. Erre számos lehetôség létezik a stratégiai tartalékoktól kezdve a termelési

9 International Renewable Energy Agency (IRENA): A New World - The Geopolitics of the Energy Transformation. 2019. https://www.irena.org/-/media/Files/IRENA/Agency/Publication/2019 /Jan/Global_commission_geopolitics_new_world_2019.pdf (Letöltés ideje: 2020. 05. 31.)

10 Yergin, Daniel: Ensuring Energy Security. Foreign Affairs, March/April 2006 Issue. https://www.foreignaffairs.com/articles/2006-03-01/ensuring-energy-security (Letöltés ideje: 2020. 05. 30.) 
kapacitások növeléséig, megfelelő tárolókapacitás vagy akár egészen konkrétan kidolgozott tervek arra vonatkozóan, hogy váratlan helyzetekben mi a teendó. A diverzifikáció és a biztonsági tartalék kialakítását pedig szükségszerúen kiegészíti egy harmadik összetevő, az integráció. Az integráció itt azt jelenti, hogy alapvetésnek kell tekinteni a kölcsönös függóség globális jellegét: az egyetlen piac stabilitásában mindenki érdekelt, és a stabil piac garantálja a biztonságot. A negyedik összetevó a megfeleló információáramlás, ami ugyancsak szorosan összekapcsolódik a fent felsorolt három összetevôvel. Ennek mára bevált és jól múködő infrastruktúrája van, hogy ezzel segítse a piac megbízható múködését, fórumot biztosít a piaci szereplóknek, így például a kormányzati és a magánszektornak, aminek különösen válsághelyzetben lehet jelentősége. Kitér továbbá olyan szegmensekre, mint az energiapolitika vagy a környezetvédelem és a klímaváltozás elleni küzdelem nemzetközi összehangolása.

Yergin a 21. század kihívásait alapul véve meghaladottnak tartja az energiabiztonságnak azt az értelmezését, amelyet a hetvenes évek olajválságaiból levont tanulságok alapján fogalmaztak meg. A globális piac és annak sebezhetósége kiterjeszti ezt az értelmezést, így tételei újabb elemekkel bóvültek. Az ellátás biztonsága mára nemcsak a stabil piac fenntartását jelenti, magába foglalja az energiaellátást biztosító teljes infrastruktúra védelmét is. Megjelenik továbbá az energiahatékonyság és az energiamegtakarítás, ami jelentốs gazdasági elónnyel jár, így hozzájárul az energiabiztonsághoz, és ez a terület hatalmas potenciált rejt magában összhangban a technológiai fejlődéssel. Az energiabiztonságnak emellett természetesen környezetvédelmi vetületei is vannak. Az energiabiztonsághoz - amibe az új technológiák fejlesztése is beletartozik - szükséges anyagi háttér megteremtéséhez folyamatos befektetésekre van szükség, így érdekeltté kell tenni a magánszektort az energetikai fejlesztésekben.

Yergin gondolatmenete alapján összességében a diverzifikáció az energiabiztonság alapvetése, ami kiegészül az energiaátmenet sajátosságaival, így a technológia fejlődésével, illetve a környezet védelmével. Különösen nagy potenciált rejt az energiahatékonyság.

\section{Magyarország céljai}

A Nemzeti Biztonsági Stratégia érdekeinkról szóló fejezetében fogalmazza meg az energiapolitika meghatározó elemeit. „Magyarország leofontosabb célkitüzése az energiapolitika terén az energiaszuverenitás és az energiabiztonság megerósítése, valamint az energiatermelés dekarbonizációja, ami csak az atomenergia alkalmazásával lehetséges. Az energiaellátási források és útvonalak diverzifikálása alapvetố és hosszú távú nemzeti érdek, ami hozzájárul hazánk stabilitásának és ellenálló képességének növeléséhez. Magyarország egyértelmü érdeke, hogy csökkentse energiaimport-szükségletét, és ezzel egyidejüleg biztosítsa mind szélesebb körü kapcsolódását a régiós áram-és földgázhálózatokhoz, ami az ellátásbiztonságot és a hatékony importversenyt tudja garantálni. Kiemelt cél az integrált európai és regionális belsô energiapiac kiépítése."

Az energiaszuverenitás és az energiabiztonság megerósítése rendkívül ambiciózus célkitúzés a stratégia által kijelölt 2030-ig terjedó tíz év alatt, tekintettel Magyarország jelenlegi nagymértékú energiafüggóségére. A szövegben nem is szerepel konkrétabban, hogy milyen indikátorok alapján tekinthetô megvalósultnak ez a megerósítés. 
Jól látszik, hogy a magyar célkitúzések egybeesnek mind az energiaunió, az uniós biztonsági stratégia, mind a NATO energiára és klímára vonatkozó biztonságpercepciójával. Daniel Yergin az energiabiztonság megteremtésére és fenntartására vonatkozó koncepciójában ugyanez az értékrend jelenik meg.

A kormány 2020. január 9-én fogadta el az új Nemzeti Energiastratégiát, ${ }^{11}$ ami 2030-ig határozza meg Magyarország energia- és klímapolitikai prioritásait. Egy héttel késóbb, január 16-án pedig bemutatott további energia- és klímapolitikai stratégiai dokumentumokat, köztük Magyarország Nemzeti Energia- és Klímatervét (NEKT), megfelelve az uniós kötelezettségnek. ${ }^{12}$ Az idôzítésból arra lehet következtetni, hogy ezek a stratégiai dokumentumok nemcsak egymással, hanem a Nemzeti Biztonsági Stratégiával is párhuzamosan, a szükséges tartalmi elemeknél egyeztetve készültek. A dokumentumok tartalma ezt megerósíti, az Energiastratégia jövóképe és a Nemzeti Energia- és Klímaterv célkitúzései csaknem szóról szóra megegyeznek a Nemzeti Biztonsági Stratégiában az ebben témában megfogalmazott célokkal.

A legnagyobb kérdés, ami az összes stratégiai dokumentumban kiemelt helyen szerepel, az energiafüggőség kérdése. A Nemzeti Biztonsági Stratégia is részletesen foglalkozik az energiafüggóség jelentette kihívásokkal, rögtön a dokumentum elején a gazdaságot érintớ alapvetések után hívja fel erre a figyelmet. A földgázellátás esetében számszerúsíti is az importfüggôséget, a 80 százalékot meghaladó arányt nemcsak az ellátásbiztonság szempontjából, hanem az importáraknak kitettség miatt is kockázatnak tekinti.

Magyarország szempontjából különösen fontos az európai energiapiacok integrációja. Az egységes piac, a közös infrastruktúrafejlesztés, a tagállamok közti szolidaritás, az energiahatékonyság, a klímavédelem, valamint a kutatást, innovációt és versenyképességet célzó intézkedések mind egybeesnek Magyarország energiabiztonsági érdekeivel. A nemzeti energiapiacok regionális szintú együttmúködése már önmagában hozzájárul az energiaunió sikeréhez. Továbbá - Magyarország nemzeti érdekeit és az EU globális stratégiáját szem előtt tartva - megfelelő alapot teremthet az Oroszországból importált gáz kiváltására a Lengyelországon vagy Horvátországon keresztül az Egyesült Államokból érkezố cseppfolyósított földgáznak. Ha pedig megindul a kitermelés a fekete-tengeri Neptun-gázmezôn, Románia felól is várható földgázszállítás, ami ugyancsak diverzifikálja az energiabeszállítók körét. ${ }^{13}$ Az Energiastratégiában és a NEKT-ben kitúzött cél, hogy a jelenlegi 80 százalékos gázimportfüggőség 2030-ra 70 százalékra csökkenjen.

11 Innovációs és Technológiai Minisztérium: Döntött a kormány Magyarország közép és hosszú távú energia és klímapolitikai prioritásairól. 2020. január 9.

https://www.kormany.hu/hu/innovacios-es-technologiai-miniszterium/hirek/dontott-a-kormany -magyarorszag-kozep-es-hosszu-tavu-energia-es-klimapolitikai-prioritasairol (Letöltés ideje: 2020. 05. 29.)

12 Innovációs és Technológiai Minisztérium: A kormány határozott stratégiai célokat túzött ki a klímaváltozás és a környezetvédelem területén. 2020. január 16.

https://www.kormany.hu/hu/innovacios-es-technologiai-miniszterium/energiaugyekert-es -klimapolitikaert-felelos-allamtitkar/hirek/a-kormany-hatarozott-strategiai-celokat-tuzott-ki-a -klimavaltozas-es-a-kornyezetvedelem-teruleten (Letöltés ideje: 2020. 05. 29.)

13 Domokos Erika: Szijjártó Péter: Magyarország nem jókedvból veszi az orosz gázt. Napi.hu, 2019. 05. 02. https://www.napi.hu/magyar_gazdasag/szijjarto-magyarorszag-nem-jokedvbol-veszi-az -orosz-gazt.683452.html (Letöltés ideje: 2020. 05. 29.) 


\section{Villamosenergia-termelés a 21. században}

Ami a biztonságunk garanciáját jelentő EU és NATO biztonságpercepciójában nem kapott szerepet, azonban a magyar stratégiai dokumentumokban hangsúlyos, az a nukleáris energia alkalmazása a villamosenergia-termelésben. A Nemzeti Biztonsági Stratégia az energiaszektorban zajló globális átalakulások várható kimeneteleit értékelve arra jut, hogy a villamos energia és a gáz felhasználásának módja változni fog, és jelentôsen megnó a villamos energia aránya. Nem vitás, az uniós szintú tervezés is arra épít, hogy az energiatermelésben és -felhasználásban egyre nagyobb szeletet hasít majd ki a villamos energia. A dokumentum a nukleáris energiától várja, hogy az ellátásbiztonság egyik alapköve legyen, valamint, hogy kibocsátáscsökkentési céljainkhoz járuljon hozzá. A NEKT és az Energiastratégia ezt tovább részletezi, és a megújuló energiaforrásoknak is kiemelt szerepet tulajdonít a klímabarát villamosenergia-termelésben.

A nukleáris energia - tekintettel a paksi beruházásra - hosszú távra meghatározza Magyarország energiapolitikájának alakulását, de itt fontos megjegyezni a dekarbonizációs célok elérésén túl néhány szempontot. A Paksi Atomerômú múködtetése a stratégiai célokkal pont ellenkezóleg, fokozza Magyarország kiszolgáltatottságát, hiszen a technológia és a fútóelemek is importból származnak. Továbbá - éppen az energiaátmenet miatt - egyre fontosabbá válik a villamosenergia-rendszerek rugalmassága, a rugalmassági szempontoknak a nukleáris energia azonban nem felel meg, így egyre nagyobb kihívást jelent majd, hogy illeszkedjen az európai vagy akár regionális energiarendszerbe. ${ }^{14}$ A nukleáris energia hasznosításával kapcsolatban örök kérdés, és fontos biztonsági, finanszírozási és energetikai vetületei is vannak, hogy a hulladék elhelyezése hol és milyen módon történik. Végül kérdés, hogy a paksi beruházás elókészületeinek csúszásai mellett valóban üzembe tudnak-e állni az új blokkok 2030 elótt ${ }^{15}$ úgy, amivel biztosítják a tólük várt kibocsátáscsökkentési célszámokat.

Új elem a 2020-as stratégiai dokumentumokban a szénkészletek stratégiai tartalékként megórzése. A dokumentum a jelenleg 8,6 milliárd tonnányi lignit, barna- és feketeszén-készletet nevezi az egyetlen, itthon is rendelkezésre álló, nem megújuló energiaforrásnak. Azt latolgatja, hogy ez több száz évre elegendó alapanyagot szolgáltathat a tiszta szén technológiák fejlődésével a diverzifikált korszerú energiaellátásban, ezért stratégiai tartalékként tervezi megórizni, és hosszú távon "megfelelő körülmények esetén gazdaságos és környezetkímélón módon hasznosítani.

Ma Magyarországon kizárólag a Mátrai Erómú múködik széntüzeléssel, így a szén stratégiai tervezése egybeesik az erómúre vonatkozó tervekkel. A NEKT

14 Felsmann Balázs, Kádár Péter, Munkácsy Béla: A fenntarthatósági szempontok érvényesülése a paksi atomerômú bóvítése kapcsán. Múhelytanulmány. Corvinus Kutatások. 2014.

https://www.researchgate.net/publication/295706167_A_fenntarthatosagi_szempontok

_ervenyesulese_a_paksi_atomeromu_bovitese_kapcsañ (Letöltés ideje: 2020. 07. 04.)

15 Szabó M. István: Már most látszik, hogy Pakssal baj lesz. Napi.hu, 2020. 05. 01.

https://www.napi.hu/magyar_gazdasag/mar-most-latszik-hogy-pakssal-baj-lesz.705190.html (Letöltés ideje: 2020. 05. 30.) 
2030-ig tervezi kivezetni a szenet a magyar piacról, ugyanakkor az erómú jelenleg 2025-ig rendelkezik engedélyekkel. ${ }^{16}$ A Mátrai Erómú további sorsa a NEKT és az Energiastratégia szerint sem eldöntött, több lehetôséget is vizsgálnak, de nem kap külön hangsúlyt, hogy a majd késóbb alkalmazott technológia is szénalapú legyen. Az említett tiszta szén technológiák még nem gyôzték meg valódi hatékonyságukról a szakmát, amit a dokumentum is sugall egyrészt a feltételes móddal, másrészt a jövóbeni fejlődés kikötésével. Mindezek alapján kérdés, hogy a 8,6 milliárd tonnányi lignit, barna- és feketeszén szolgálhat-e valóban stratégiai tartalékként hosszú távon, ha nem lesz olyan erómú, ami alkalmas ezek elégetésére. A terv megalapozottságát mutatja ugyanakkor, hogy idén márciusban zárult le az a tranzakció, ${ }^{17}$ melyben az állam megvásárolta a Mátrai Erómúvet. Összességében azonban fontos leszögezni, hogy a szénalapú energiatermelés elavult, káros a környezetre, hátráltatja a klímavédelmi célok megvalósulását, ezért nem kéne, hogy egy fejlett gazdaságú ország stratégiai dokumentumai hosszú távon tervezzenek vele. ${ }^{18}$

\section{Kiemelt biztonsági kockázatok}

A dokumentum összesen 17 pontba szedve priorizálja a kiemelt biztonsági kockázatokat. Az energia és klíma területét érintő kockázatok közül a 4. helyre került a jelentôs károkat okozó kibertámadás, ami érinthet például kritikus energetikai infrastruktúrát, és ezzel veszélybe sodorhatja az ellátás biztonságát. A kiberbiztonság pont ebben az értelemben szorosan összefügg az energiabiztonsággal, és a digitalizáció terjedésével valóban egyre nó a sebezhetôség.

A 9. helyre sorolták azt a Magyarország energiaimport-függóségéból adódó kockázatot, hogy az energiaszállítás fennakadása ellátási válsághelyzetet okozhat. Ez az energiafüggóség mértékét tekintve kissé nagyvonalú besorolásnak túnik, hiszen a teljes gazdaság múködése kerülhet így veszélybe, amire egyébként egy másik pontban ki is tér a dokumentum. Összehasonlításként az EU globális stratégiájában az elsô öt veszélyforrás között említi az energiabiztonság hiányát.

A 14. helyen szerepelnek a regionális hatással járó ipari balesetek és katasztrófák, amire földrajzilag közelfekvő példa az 1986-ban történt csernobili atomkatasztrófa. Sajnos azonban az atomerômúvekben rejlő kockázatok nem maradtak az előző évezredben, elég csak a 2011-es fukusimai atomkatasztrófára gondolni.

A 16. helyre kerültek a szélsóséges idójárás okozta rendszeres pusztítások és természeti katasztrófák. Ugyan külön pontba kerültek, de szorosan összefüggenek a 17. helyre sorolt kockázatok, ahol már a klímaváltozással indokolják a természetes folyamatok kedvezótlen alakulását, így a csapadékmentes idójárást és a talaj kiszáradását, amelyek

16 Mátrai Erómú. http://www.mert.hu/hu/elotet-gazturbin (Letöltés ideje: 2020. 05. 30.)

17 Ezért vásárolja meg az állam a Mátrai Erômúvet. Origo, 2020. 03. 26. https://www.origo.hu/itthon /20200326-ezert-vasarolja-meg-az-allam-a-matrai-eromuvet-origo.html (Letöltés ideje: 2020. 05. 30.)

18 Dr. Munkácsy Béla, Csontos Csaba, Gyóri Kata, Magyar László, Dr. Sáfián Fanni: Magyarország Nemzeti Energia- és Klímatervének értékelése a fenntartható energiagazdálkodás nézópontjából. Energiaklub 2020. június. 18. o. https://www.energiaklub.hu/files/study/Energiaklub\% 20NEKT \%20v\% C3\%A9lem\%C3\%A9ny.pdf (Letöltés ideje: 2020. 07. 04.) 
hatására sérül a biodiverzitás. A dokumentum a klímaváltozást csak az utolsó, 17. pontban említi nevén, miközben nyilvánvalóan a 16. pont tartalma is teljesen lefedi a klímaváltozás megvalósulási formáit, tehát ez a két pont egybevonása indokoltnak túnik, ahogyan az is, hogy lényegesen feljebb kerüljön a listán. A klímaváltozás számos, feljebb említett kockázattal is szoros összefüggést mutat, különösen az energia hasznosításának egyes kérdéseivel, hiszen egyik sajátossága, ahogy egyébként azt a dokumentum részben a klímaváltozásra utalva korábban meg is jegyzi, hogy multiplikátorként képes folyamatokat összekapcsolni, felgyorsítani, és komplex kihívásokat generálni, így a biztonságra közvetlen hatást gyakorolni. Természetesen a prioritások objektíven nehezen határozhatóak meg, a magyar társadalom biztonságpercepciójáról szóló kutatás azonban konkrét információt nyújt.

Az NKE Stratégiai Védelmi Kutatóintézet (SVKI) 2019 decemberében végzett reprezentatív felmérést a magyar lakosság körében. ${ }^{19}$ A megkérdezettek közül a legtöbben, 36,8 százalék gondolta úgy, hogy a klímaváltozás negatív hatást gyakorol Magyarország biztonságára. Majdnem ugyanennyien, 36,6 százalék vélekedett ugyanígy az illegális migrációról. A megkérdezettek 30 százaléka sorolta a gázimportfüggőséget a biztonságra negatív hatást gyakorló tendenciák közé, ami így a harmadik helyre került. Az elemzés szerint ez feltehetôen szorosan kapcsolódik a klímaváltozáshoz köthetó félelmekhez, és valószínúleg ebból következik az az általános vélemény, hogy a megújuló energiák részarányának növelésével kell fenntarthatóbbá tenni az energiamixet.

A lakossági kutatásban elókerült az energiabiztonság kérdése is, a megkérdezettek 32 százaléka látna szívesen V4-es kooperációt a témában. A környezeti biztonság és klímapolitika területén 30,3 százaléka vár együttmúködést a V4-ektól. A kutatás szerint a magyar lakosság biztonságpercepciója a NATO és EU kiemelt szerepében Magyarország biztonságában teljességgel megegyezik a Nemzeti Biztonsági Stratégiában foglaltakkal.

Az SVKI kutatásában megkérdeztek a magyar biztonságpolitikai stratégiát alkotó szakembereket is, közülük azonban csak néhány érintette a fenti, a társadalom számára kiemelten fontos témákat. Néhányan a klímaváltozást említették, de inkább a migráció kiváltó okaként, és nem általánosabb kontextusban. Mindössze egy szakember beszélt a globális gazdaság kihívásainak Magyarországra gyakorolt hatásairól és ennek biztonsági vetületeiról, és szintén egy szakember vetette fel az energia témájában a diverzifikáció kérdését.

\section{Magyarország a globális közösségben}

A dokumentum a nemzeti biztonság feltételének tekinti, hogy Magyarország részese legyen a globális közösségnek, és hozzájáruljon a fenntartható, globális növekedéshez, azaz hogy képes legyen a politikai és gazdasági együttmúködésre az érdekelt államokkal.

19 Etl Alex: The perception of security in Hungary. ISDS Analyses, 2020/3. 2020. 03. 04.

https://svkk.uni-nke.hu/document/svkk-uni-nke-hu-1506332684763/ISDS_Analyses_2020_3_The\%20 perception\%20of\%20security\%20in\%20Hungary_(Alex\%20Etl)\%20(1).pdf (Letöltés ideje: $\overline{2} 0 \overline{2} 0.05 .31$.) 
A dokumentum ugyancsak globális kontextusban említi növekvő kockázati tényezóként a gazdasági növekedés esetleges lassulását és az ebból fakadó gazdasági és pénzügyi instabilitást. Ebból következően Magyarország érdekei közé sorolja a nemzetközi gazdasági konjunktúra fenntartását. A stratégia tehát amellett érvel, hogy a tartós gazdasági növekedés az útja a gazdasági mozgásterünk szélesítésének. Azt is mondja ugyanakkor, hogy "a fenntartható társadalmi és gazdasági fejlődés, továbbá a természeti katasztrófák megelózésének egyik kritikus feltétele az éghajlatváltozás hatásainak mérséklése, a gazdaság fosszilis energiahordozó-igényének csökkentése érdekében a környezettudatos és karbonszegény életmód népszerüsitése".

Egyes közgazdasági elméletek szerint a tartós gazdasági növekedés ellentmond a fenntarthatóságnak, ezen irányzatok egy olyan társadalmi és gazdasági berendezkedést tartanak kívánatosnak, ahol a termelés és a fogyasztás nem növekszik, mégis nagyobb a jóllét, és mindezzel párhuzamosan jelentósen csökken a környezeti terhelés. ${ }^{20}$ Ha pedig a gazdasági növekedésnek kizárólag az energiára gyakorolt hatását nézzük, fontos kihangsúlyozni az energiahatékonyság szerepét, aminek a lényege azoknak a technológiáknak a támogatása, amelyekkel minél kevesebb az energiafelhasználás. Ugyancsak fontos tényező, hogy az olcsó energia fellendíti a gazdaságot, és ha a fenntarthatóságot szem elótt akarjuk tartani, akkor a megújuló energiaforrások jelentik a megoldást.

A stratégia összességében tartalmaz minden olyan szempontot, értéket és célt, amelyek alkalmassá teszik, hogy irányt mutasson a 21. század energia- és klímabiztonságot érintố kihívásaira. Jól látszik azonban az is, hogy bármennyire is modern a stratégia energiabiztonságot érintố tartalma, a szélesebb társadalom és a biztonságpolitikát alakító elit biztonságpercepciója lényeges különbségeket mutat, és egyes, napjaink kihívásai szempontjából fontos tudományos irányzatok nem vagy csak utalás szintjén jelennek meg a tartalomban. A 2020-as stratégia ezzel együtt is részletesebben és alaposabban foglalkozik az energia és a klíma kérdéseivel, mint a 2012-ben született elődje. Ez nem meglepó abból a szempontból, hogy ezeknek a területeknek a biztonságra gyakorolt hatása jelentősen felértékelődött.

A két dokumentum között meghatározó különbség, hogy 2012-ben egy-egy külön pont foglalkozott az energia és a klíma kérdéseivel részletesebben, a friss dokumentum továbbmegy, és ezeket a területeket nem elszigetelt egységekként kezeli. Most komplexen megjelennek a bennük rejlő kihívások és kockázatok a biztonság más területein is, majd a dokumentum megoldási javaslatokat is tesz. Az elózó stratégia megalkotása óta eltelt nyolc év fejleményei mindezt indokolják is: a 2015-ös Párizsi Klímaegyezmény, az energiaunió létrehozása, az energiaszektor globális átalakulása, a megújuló energiák térnyerése, a klímaváltozás felgyorsulásával párhuzamos dekarbonizációs törekvések, a szélsőséges idójárási jelenségek mezőgazdaságra, élelmiszerbiztonságra gyakorolt hatásai stb.

20 Dombi Judit - Málovics György: A növekedésen túl - egy új irányzat hozzájárulása a fenntarthatósági vitához. Közgazdasági Szemle, LXII. (2015. február), 206-208. o.

http://real.mtak.hu/21302/1/04_DombiMalovics_u_170743.308539.pdf (Letöltés ideje: 2020. 05. 31.) 


\section{Összegzés}

A magyar stratégiai dokumentumok alapvetôen tartalmazzák mindazokat az elemeket, amelyeket az elemzés szempontjaiként jelöltünk ki. Megfelelnek a biztonsági garanciának tekintett EU és NATO biztonságpercepciójának, és kivétel nélkül szerepelnek bennük a Daniel Yergin energiabiztonságról szóló elméleti koncepciójának elemei. Az energia és hozzá köthetően a klíma témájához, valamint az energiabiztonsághoz kapcsolódó magyar stratégiai dokumentumok is tartalmilag mind összhangban vannak egymással.

A politikai döntéshozók és a lakosság biztonságpercepciójában már korántsem ekkora az összhang, ennek ellenére a vizsgált témák egy modern, a 21. század kihívásait ismeró szemléletmódot tükröznek. Egyes elemeiben mégis felfedeztünk logikai buktatókat, amelyek ellentmondanak a 21. század elvárásainak.

Kérdés például, hogy ha Magyarország egyetlen széntüzelésú erômúve, a Mátrai Erômú 2025-ig rendelkezik engedélyekkel, akkor hogyan képzelik a szénkészlet hasznosítását hosszú távú stratégiai tartalékként. Fontos azt is leszögezni, hogy a szénalapú energiatermelés elavult, káros a környezetre, hátráltatja a klímavédelmi célok megvalósulását, ezért nem kéne, hogy egy fejlett gazdaságú ország stratégiai dokumentumai hosszú távon tervezzenek vele.

Kérdés továbbá, hogy a paksi bővítés képes lesz-e beváltani a hozzá fúzött reményeket, hiszen nem rendelkezik a modern energiarendszerekhez szükséges rugalmassággal, illetve egyelőre az sem biztos, hogy 2030 elótt el tud kezdeni termelni, és produkálja az elvárt kibocsátáscsökkentési célszámokat.

Nem világos az sem, hogy a célul kitúzött energiaszuverenitás és energiabiztonság megerősítése milyen indikátorok alapján számít teljesítettnek, hiszen Magyarország importfüggósége rendkívül magas. Az energiaszuverenitás szempontjából pedig különösen fontos lenne a stratégiában valamelyest alulkezelt megújuló energiaforrások szerepe, valamint a gazdasági növekedés, mint fejlődési irány megkérdôjelezése és az ahhoz szükséges energiaigény érdemi vizsgálata.

Végül, de nem utolsó sorban, az uniós célkitúzések és a gazdasági szempontok mérlegelése a biztonsági kockázatok értékelésében kevésbé jelenik meg. Kérdés, hogy ez nem áll-e majd útjába annak, hogy a dokumentumokban szerepló fenntartható energiagazdálkodási célok megvalósuljanak.

\section{FELHASZNÁLT IRODALOM}

A Kormány 1035/2012. (II. 21.) Korm. határozata Magyarország Nemzeti Biztonsági Stratégiájáról A Kormány 1163/2020. (IV. 21.) Korm. határozata Magyarország Nemzeti Biztonsági Stratégiájáról A Kormány 2073/2004. (IV. 15.) Korm. határozat a Magyar Köztársaság nemzeti biztonsági stratégiájáról A Kormány 2144/2002. (V. 6.) Korm. határozat a Magyar Köztársaság Nemzeti Biztonsági Stratégiájáról Dombi Judit - Málovics György: A növekedésen túl - egy új irányzat hozzájárulása a fenntarthatósági vitához. Közgazdasági Szemle, LXII. (2015. február), 206-208. o.

http://real.mtak.hu/21302/1/04_DombiMalovics_u_170743.308539.pdf (Letöltés ideje: 2020. 05. 31.)

Domokos Erika: Szijjártó Péter: Magyarország nem jókedvból veszi az orosz gázt. Napi.hu, 2019. 05. 02. https://www.napi.hu/magyar_gazdasag/szijjarto-magyarorszag-nem-jokedvbol-veszi -az-orosz-gazt.683452.html (Letöltés ideje: 2020. 05. 29.) 
European Commission: Energy Union.

https://ec.europa.eu/energy/topics/energy-strategy/energy-union_en (Letöltés ideje: 2020. 05. 30.)

Etl Alex: The perception of security in Hungary. ISDS Analyses, 2020/3. 2020. 03. 04. https://svkk.uni-nke.hu/document/svkk-uni-nke-hu-1506332684763/ISDS Analyses 2020 3_The\%20perception\%20of\%20security\%20in\%20Hungary_(Alex\% $\overline{\%} 20 \mathrm{Etl}) \% 20(1)$.pdf (Letöltés ideje: 2020. 05. 31.)

Ezért vásárolja meg az állam a Mátrai Erómúvet. Origo, 2020. 03. 26. https://www.origo.hu/itthon/20200326-ezert-vasarolja-meg-az-allam-a-matrai -eromuvet-origo.html (Letöltés ideje: 2020. 05. 30.)

Felsmann Balázs, Kádár Péter, Munkácsy Béla: A fenntarthatósági szempontok érvényesülése a paksi atomerômú bővítése kapcsán. Múhelytanulmány (working paper). Corvinus Kutatasok. 2014. https://www.researchgate.net/publication/295706167_A_fenntarthatosagi_szempontok _ervenyesulese_a_paksi_atomeromu_bovitese_kapcsan (Letöltés ideje: 2020. 07. 04.)

Innovációs és Technológiai Minisztérium: A kormány határozott stratégiai célokat túzött ki a klímaváltozás és a környezetvédelem területén. 2020. január 16.

https://www.kormany.hu/hu/innovacios-es-technologiai-miniszterium/energiaugyekert-es -klimapolitikaert-felelos-allamtitkar/hirek/a-kormany-hatarozott-strategiai-celokat-tuzott-ki-a -klimavaltozas-es-a-kornyezetvedelem-teruleten (Letöltés ideje: 2020. 05. 29.)

Innovációs és Technológiai Minisztérium: Döntött a kormány Magyarország közép és hosszú távú energia és klímapolitikai prioritásairól. 2020. január 9.

https://www.kormany.hu/hu/innovacios-es-technologiai-miniszterium/hirek/dontott-a -kormany-magyarorszag-kozep-es-hosszu-tavu-energia-es-klimapolitikai-prioritasairol (Letöltés ideje: 2020. 05. 29.)

International Energy Agency: Energy security. https://www.iea.org/topics/energysecurity/ (Letöltés ideje: 2020. 05. 30.)

International Renewable Energy Agency (IRENA): A New World - The Geopolitics of the Energy Transformation. 2019.

https://www.irena.org///media/Files/IRENA/Agency/Publication/2019/Jan/Global_commission _geopolitics_new_world_2019.pdf (Letöltés ideje: 2020. 05. 31.)

Közös jövókép, közös fellépés: Erôsebb Európa - Globális stratégia az Európai Unió kül- és biztonságpolitikájára vonatkozóan.

http://www.eeas.europa.eu/archives/docs/top_stories/pdf/eugs_hu_pdf (Letöltés ideje: 2020. 05. 31.)

Mátrai Erómú. http://www.mert.hu/hu/elotet-gazturbin (Letöltés ideje: 2020. 05. 30.)

Dr. Munkácsy Béla, Csontos Csaba, Gyốri Kata, Magyar László, Dr. Sáfián Fanni: Magyarország Nemzeti Energia- és Klímatervének értékelése a fenntartható energiagazdálkodás nézópontjából. Energiaklub, 2020. június 18. https://www.energiaklub.hu/files/study/Energiaklub

\%20NEKT\%20v\% C3\%A9lem\% C3\%A9ny.pdf (Letöltés ideje: 2020. 07. 04.)

NATO's role in energy security. 14 September 2018. https:/www.nato.int/cps/en/natohq/topics_49208.htm (Letöltés ideje: 2020. 05. 31.)

Szabó M. István: Már most látszik, hogy Pakssal baj lesz. Napi.hu, 2020. 05. 01. https://www.napi.hu/magyar_gazdasag/mar-most-latszik-hogy-pakssal-baj-lesz.705190.html (Letöltés ideje: 2020. 05. 30.)

Yergin, Daniel: Ensuring Energy Security. Foreign Affairs, March/April 2006 Issue. https://www.foreignaffairs.com/articles/2006-03-01/ensuring-energy-security (Letöltés: 2020. 05. 30.) https://doi.org/10.2307/20031912 